\title{
Comparative chemical profiling, cholinesterase inhibitions and anti-radicals properties of essential oils from Polygonum hydropiper L: A Preliminary anti- Alzheimer's study
}

Muhammad Ayaz*, Muhammad Junaid ${ }^{1}$, Farhat Ullah¹, Abdul Sadiq ${ }^{1}$, Mir Azam Khan ${ }^{1}$, Waqar Ahmad ${ }^{1}$, Muhammad Raza Shah², Muhammad Imran ${ }^{1,2}$ and Sajjad Ahmad ${ }^{1}$

\begin{abstract}
Background: Cholinesterase inhibition is a vital target for the development of novel and mechanism based inhibitors, owing to their role in the breakdown of acetylcholine (ACh) neurotransmitter to treat various neurological disorders including Alzheimer's disease (AD). Similarly, free radicals are implicated in the progression of various diseases like neurodegenerative disorders. Due to lipid solubility and potential to easily cross blood brain barrier, this study was designed to investigate the anticholinesterase and antioxidant potentials of the standardized essential oils from the leaves and flowers of Polygonum hydropiper.
\end{abstract}

Methods: Essential oils from the leaves (Ph.LO) and flowers (Ph.FO) of P. hdropiper were isolated using Clevenger apparatus. Oil samples were analyzed by GC-MS to identify major components and to attribute the antioxidant and anticholinesterase activity to specific components. Acetylcholinesterase (AChE) and butyrylcholinesterase (BChE) inhibitory potentials of the samples were determined following Ellman's assay. Antioxidant assays were performed using 1,1-diphenyl,2-picrylhydrazyl (DPPH), 2,2-azinobis[3-ethylbenzthiazoline]-6-sulfonic acid (ABTS) and hydrogen peroxide $\left(\mathrm{H}_{2} \mathrm{O}_{2}\right)$ free radical scavenging assays.

Results: In the GC-MS analysis 141 and 122 compounds were indentified in Ph.LO and Ph.FO respectively. Caryophylene oxide (41.42\%) was the major component in Ph.FO while decahydronaphthalene (38.29\%) was prominent in Ph.LO. In AChE inhibition, Ph.LO and Ph.FO exhibited $87.00^{* *}$ and $79.66^{* * *} \%$ inhibitions at $1000 \mu \mathrm{g} / \mathrm{ml}$ with $I_{50}$ of 120 and $220 \mu \mathrm{g} / \mathrm{ml}$ respectively. The $I_{50}$ value for galanthamine was $15 \mu \mathrm{g} / \mathrm{ml}$. In BChE inhibitory assay, Ph.LO and Ph.FO caused 82.66*** $\left(\mathrm{IC}_{50} 130 \mu \mathrm{g} / \mathrm{ml}\right)$ and $77.50^{* * * \%}$ ( $\left(\mathrm{C}_{50} 225 \mu \mathrm{g} / \mathrm{ml}\right)$ inhibitions respectively at $1000 \mu \mathrm{g} / \mathrm{ml}$ concentration. In DPPH free radical scavenging assay, Ph.LO and Ph.FO exhibited IC 50 of 20 and $200 \mu \mathrm{g} / \mathrm{ml}$ respectively. The calculated $\mathrm{IC}_{50} \mathrm{~S}$ were $180 \& 60 \mu \mathrm{g} / \mathrm{ml}$ for Ph.LO, and $45 \& 50 \mu \mathrm{g} / \mathrm{ml}$ for Ph.FO in scavenging of ABTS and $\mathrm{H}_{2} \mathrm{O}_{2}$ free radicals respectively.

Conclusions: In the current study, essential oils from leaves and flowers of $P$. hydropiper exhibited dose dependent anticholinesterase and antioxidant activities. Leaves essential oil were more effective and can be subjected to further in-vitro and in-vivo anti-Alzheimer's studies.

Keywords: Polygonum hydropiper, Essential oils, GC-MS, Anticholinesterase and antioxidant

\footnotetext{
* Correspondence: ayazuop@gmail.com

'Department of Pharmacy, University of Malakand, Khyber pakhtoonkhwa (KPK) 18000, Pakistan

Full list of author information is available at the end of the article
}

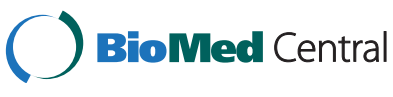

(c) 2015 Ayaz et al. Open Access This article is distributed under the terms of the Creative Commons Attribution 4.0 International License (http://creativecommons.org/licenses/by/4.0/), which permits unrestricted use, distribution, and reproduction in any medium, provided you give appropriate credit to the original author(s) and the source, provide a link to the Creative Commons license, and indicate if changes were made. The Creative Commons Public Domain Dedication waiver (http://creativecommons.org/publicdomain/zero/1.0/) applies to the data made available in this article, unless otherwise stated. 


\section{Background}

The cholinergic concept of Alzheimer's disease (AD) was initially resulted from postmortem studies of the brain $[1,2]$, which ultimately led to the development of new drugs based on the inhibition of the key enzymes acetylcholinesterase (AChE) and butyrylcholinesterase $(\mathrm{BChE})[3,4]$. Therapy with such drugs resulted in a significant improvement in cognitive functions and also hampered the progression of the disease [5-7]. Two cholinesterases, $\mathrm{AChE}$ encoded by gene on chromosome 7 and $\mathrm{BChE}$ encoded by gene on chromosome 3 occur in the human central nervous system (CNS) $[8,9]$. These enzymes share about $65 \%$ amino acid sequence homology even though coded on different genes [10]. In the human brain BChE mostly appears to have a neuroglial distribution, while $\mathrm{AChE}$ is principally located within cholinergic axons and in the neuronal cell bodies. Both enzymes are also present in neuritic plaques and tangles in $\mathrm{AD}$ patients $[11,12]$. The ratio of cholinesterases in the human brain varies during the course of $\mathrm{AD}$. A decline of $10-15 \%$ in the activity of AChE in the hippocampus and cerebral cortex has been reported in advanced stages of the disease, whereas BChE activity increases by $40-90 \%[11,13]$. These changes in the ratio of cholinesterases and variation in the level of the neurotransmitters in dementia must be considered in order to optimize the therapeutic balance between AChE and $\mathrm{BChE}$ inhibitions. This balance may be sustained via the selective or non-selective inhibition of the enzymes. A significant correlation between the inhibition of $\mathrm{BChE}$ activity in the cerebrospinal fluid (CSF), but not AChE, with an enhancement in cognitive performance in patients with mild to moderate AD after treatment with rivastigmine (non-specific inhibitor of cholinesterases) has been reported [14]. Experimental data also revealed that $\mathrm{BChE}$ specific inhibitors not only raise the levels of acetylcholine ( $\mathrm{ACh})$ in rats but also improve memory in elderly rats $[9,15]$. These findings also signify that inhibition of $\mathrm{BChE}$ in addition to AChE may be vital in the treatment of Alzheimer's type dementia.

A currently available drug like tacrine is observed to have severe side effects like liver transaminase elevations and gastrointestinal complainsts [16], and are only useful in mild type of $\mathrm{AD}$ [17]. Therefore, it is required to search new, safe and effective drug candidates. Natural products are potential sources of novel bioactive compounds and have an extensive history of therapeutic utility since the establishment of human era. Galanthamine, an anticholinestrase alkaloid was isolated from snowdrop, and is approved for the therapy of AD [18]. Research has been directed to study the biological effects of plants traditionally used as cholinesterase inhibitors $[18,19]$.
Free radicals including reactive oxygen species (ROS) are implicated in a variety of disorders including neuroinflammation, gastritis, ischemic heart diseases, reperfusion injury of tissues and atherosclerosis [20, 21]. Free radicals generated during oxidation process are converted to non-radical forms by catalase and hydroperoxidase enzymes in living systems. But in case of excessive radical generation or depletion of human immune system natural antioxidants as free radical scavengers may be required [22]. In Alzheimer's patients and aging brain, dysfunctional mitochondria generate free radicals, thus lead to oxidative stress followed by oxidative damage and pathological changes. $\beta$-amyloid $(A \beta)$ is a powerful originator of reactive oxygen and nitrogen species which are primary initiators of oxidative harm thus effecting neural, microglial, cerebrovascular cells and tissues [23]. Currently, available synthetic antioxidants including gallic acid esters, tertiary butylated hydroquinone and butylated hydroxy toluene (BHT) are associated with adverse health consequences [24]. Numerous natural bioactive compounds have been shown to possess strong antioxidant potential which reveals that these compounds have the ability to scavenge free radicals inside the body and provide very low chances of adverse effects $[25,26]$.

Among plants which have been investigated for the treatment of neurodegenerative disorders, Polygonum hydropiper is one of the most numerous genuses in the family Polygonaceae which is abundant in North West of Pakistan. This plant has a long history of use in folk medicine as remedy for the treatment of a multiplicity of disorders including inflammation, rheumatoid arthritis, epilepsy, headache, colic pain, fever, chill, joint pain, oedema and infectious diseases [27-29]. It is also used as diuretic, CNS stimulant, anthelmintic, to treat insomnia, kidney diseases, hemorrhoids, hypertension and angina [30]. Other species of Polygonaceae family have been reported for their effectiveness in Parkinson's disease [31], cerebral ischemia [32] and neuroprotective agents [33]. We recently reported the solvent extracts of $P$. hydropiper for antioxidant, anticholinestrase activities and its potential effectiveness to treat neurodegenerative disorders [29]. Volatile constituents of the essential oils from $P$. hydropiper are expected to readily cross the blood-brain barrier owing to their small molecular size and lipophilic nature. Their volatile nature may also facilitate their administration in the form of inhalation avoiding the alimentary canal with its attendant denaturing of active molecular species.

\section{Results}

GC-MS analysis of samples

In GC, GC-MS analysis of Ph.LO, 141 compounds were identified (as shown in Fig. 1) among which 


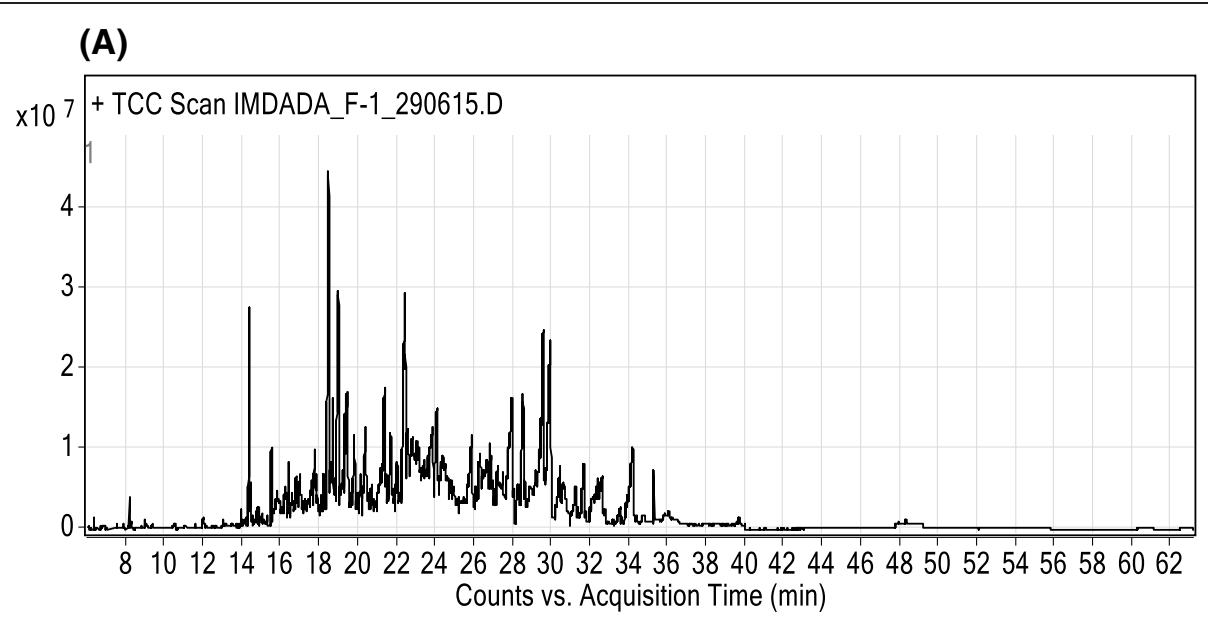

(B)

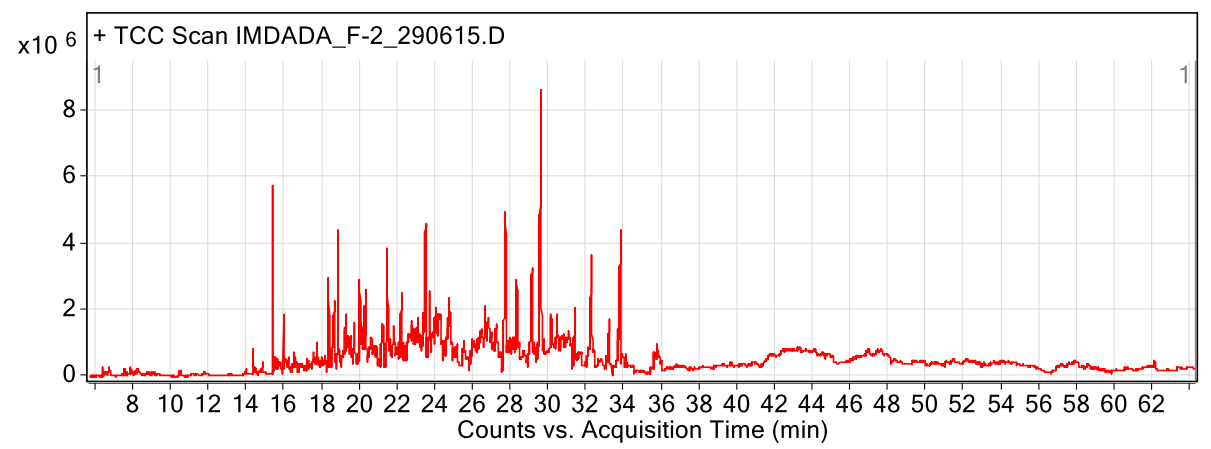

Fig. 1 GC-MS chromatogram of essential oils from leaves (a) and flowers (b) of Polygonum hydropiper

decahydronaphthalene (38.29\%), bicyclo [2.2.2] oct-2ene, 1,2,3,6-tetramethyl (36.33\%), $\beta$-elemene cis-1,3-diisopropenyl-trans-4-vinyl-4-methylcyclohexane (6.81\%), cis-geranylacetone (3.72 \%), $\beta$-caryophyllene epoxide $(2.69 \%)$ were in higher concentrations as shown in Fig. 2, Table 1(A) (The details of all compounds identified in the leaf oil is shown in Additional file 1: Table S1 in supporting information). In analysis of Ph.FO, caryophylene oxide (41.42\%), beta caryophyllene epoxide (18.17\%), humulene oxide (16.09\%), $\beta$-elemene cis-1,3-diisopropenyl-trans-4-vinyl-4-methylcyclohexane (4.76\%), 3,5-diisopropenyl-1,1,2-trimethylcyclohexane (3.83\%) and limonene $(1.79 \%)$ were in high concentrations as given in Fig. 3, Table 1(B) (The details of all compounds identified in the leaf oil is shown in Additional file 2: Table S2 in supporting information).

\section{Cholinesterase inhibition assays}

The acetyl and butyrylcholinesterase inhibitions potentials of essential oils isolated from leaves and flowers of P. hydropiper are shown in Table 2.

\section{Acetylcholinesterase (AChE) inhibition assay}

In acetylcholinesterase (AChE) inhibition assay, essential oils from leaves (Ph.LO) exhibited 87.00 $\pm 1.15^{* *}, 71.00 \pm$ $0.57 * \%, \quad 63.66 \pm 0.33^{* * * *}, \quad 57.33 \pm 0.88^{* * * *}, \quad 52.00 \pm 1.52 * \% *$, $44.66 \pm 1.20^{* * * *}, 36.50 \pm 0.44^{* * * * *}$ and $28.00 \pm 0.57^{* * * * \% ~ \% ~ i n h i b-~}$ ition at concentrations of 1000, 500, 250, 125, 100, 50, 25 and $12.50 \mu \mathrm{g} / \mathrm{ml}$ respectively. Likewise, essential oils from flowers (Ph.FO), showed $79.66 \pm 0.88^{* * * *}, 61.66 \pm 1.20^{* * * *}$ and $55.00 \pm 1.00 \% * \%, 49.00 \pm 0.00 \% * \%, 43.33 \pm 1.45^{* * * *}, 35.00$ $\pm 0.57^{* * * *}, 28.00 \pm 1.15^{* * * *}$ and $21.66 \pm 0.66^{* * * \% \%}$ inhibitions at concentrations of 1000, 500, 250, 125, 100, 50, 25 and $12.50 \mu \mathrm{g} / \mathrm{ml}$ respectively. Highest AChE inhibitions from standard drug galanthamine were $92.33 \pm 0.33,87.00 \pm$ $1.20,83.33 \pm 0.66,77.00 \pm 0.00$ and $72.00 \pm 2.64 \%$ at concentration of 1000, 500, 250, 125 and $100 \mu \mathrm{g} / \mathrm{ml}$ respectively. The $\mathrm{IC}_{50}$ for Ph.LO, Ph.FO and galanthamine were 120,220 and $15 \mu \mathrm{g} / \mathrm{ml}$ respectively.

\section{Butyrylcholinesterase (BChE) inhibition assay}

In Butyrylcholinesterase (BChE) inhibition assay, high-

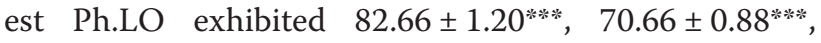
$61.00 \pm 1.15^{* * * *}$ and $52.00 \pm 0.57^{* * *}, \quad 48.66 \pm 1.20^{* * *}$, 
<smiles>C=C(C)C1CCC(C)(C(=C)C)C(C(=C)C)C1</smiles>

a<smiles>C=C(C)C1CCC(C)=C2CCC(C)C2C1</smiles><smiles>CC1CC2CCC1(C)C(C)C2</smiles>

g<smiles>CCCC1CCCCC1CC</smiles><smiles>CC(=O)CCC1C(C)=CCCC1(C)C</smiles>

b<smiles>OCC1C2CCC(C3CC3)CC12</smiles>

e<smiles>CC1C(C)(C)C=CC12CCC(O)C1(C)CCC(C)(C)C12</smiles>

h<smiles>CC(=O)CC/C=C(/C)CCC=C(C)C</smiles>

C<smiles>C=CC(C)(O)CCCC(C)CCCC(C)C</smiles>

f<smiles>C=C1CCC2OC2(C)CCC1C1CC1(C)C</smiles>

Fig. 2 Major identified compounds in the GC-MS analysis of essential oils from leaves of Polygonum hydropiper (a) 1-Methyl-1,2,4-tri(prop-1-en-2-yl)cyclohexane (b) 4-(2,6,6-Trimethylcyclohex-2-enyl)butan-2-one (c) (Z)-6,10-dimethylundeca-5,9-dien-2-one (d) (Z)-1,2,3,5,6,7,8,8a-octahydro-1,4-dimethyl-7(prop-1-en-2-yl)azulene (e) 3-Cyclopropylbicyclo[4.1.0] heptan-7-yl)methanol (f) 3,7,11-Trimethyldodec-1-en-3-ol (g) 1,2,3,6-Tetramethylbicyclo[2.2.2] oct-2-ene (h) (1R,5S,8R,9R)-4,4,8-trimethyltricyclo[6.3.1.0(1,5)]dodeca-2-en-9-ol (i) b-Caryophyllene epoxide (j) Decahydronaphthalene

$40.33 \pm 0.88^{* * * *}, \quad 31.00 \pm 1.15^{* * *}$ and $20.66 \pm 1.20 * \% * \%$ enzyme inhibitions at concentrations of 1000,500 , $250,125,100,50,25$ and $12.50 \mu \mathrm{g} / \mathrm{ml}$ respectively. Furthermore, Ph.FO showed $77.50 \pm 0.44^{* * *}, 64.00 \pm$ $0.00^{* * * *}, 53.66 \pm 0.88^{* * * *}, 46.66 \pm 1.20 * * *, 35.00 \pm 0.16^{* * * *}$, $27.33 \pm 0.33^{* * * * *}, 23.00 \pm 1.15^{* * * *}, 18.00 \pm 0.57^{* * * * \%} \%$ BChE inhibitions at concentrations of 1000, 500, 250, 125, $100,50,25$ and $12.50 \mu \mathrm{g} / \mathrm{ml}$ respectively. Galanthamine revealed $96.00 \pm 1.52,92.33 \pm 0.66,89.33 \pm 1.45$, $86.66 \pm 1.76, \quad 81.00 \pm 0.00, \quad 77.66 \pm 1.20, \quad 70.00 \pm 1.52$ and $60.00 \pm 0.57 \%$ inhibitions at the same concentrations. The $\mathrm{IC}_{50}$ calculated from dose response curve were 130, 225 and $10 \mu \mathrm{g} / \mathrm{ml}$ for Ph.LO, Ph.FO and galanthamine respectively.

\section{Antioxidant assays}

The antioxidant potentials of essential oils from leaves and flowers of $P$. hydropiper were determined using DPPH, ABTS and $\mathrm{H}_{2} \mathrm{O}_{2}$ free radicals. The results are summarized in Table 3.

\section{DPPH assay}

In DPPH free radicals scavenging assay, Ph.LO exhibited $85.00 \pm 1.15^{* * *}, 79.50 \pm 0.28^{* * * * *}, 72.00 \pm 1.04^{* * * *}, 65.16 \pm$ $0.60 \%, 60.66 \pm 0.92 \%$ and $53.50 \pm 0.86,46.66 \pm 0.72$ and $37.95 \pm 0.29 \% * \%$ inhibitions at concentrations of 1000 , $800,400,200,100,50,25$ and $12.50 \mu \mathrm{g} / \mathrm{ml}$ respectively. For Ph.FO highest DPPH scavenging activities observed were, $81.33 \pm 0.72^{* * * * *}, 70.16 \pm 0.60^{* * * *}, 54.83 \pm 2.92^{* * * * *}$ at concentrations of 1000,800 and $400 \mu \mathrm{g} / \mathrm{ml}$ respectively. The $\mathrm{IC}_{50}$ calculated from dose-response curve were 20 and $200 \mu \mathrm{g} / \mathrm{ml}$ for Ph.LO \& Ph.FO respectively. Ascorbic acid demonstrated $91.90 \pm 0.96,87.08 \pm 0.47,79.85 \pm$ $2.24,68.36 \pm 0.57$ and $63.00 \pm 1.15 \%$ inhibitions at concentrations of 1000, 800, 400, 200 and $100 \mu \mathrm{g} / \mathrm{ml}$ respectively attaining an $\mathrm{IC}_{50}$ of $5 \mu \mathrm{g} / \mathrm{ml}$.

\section{ABTS assay}

In ABTS free radicals scavenging assay, $89.00 \pm 0.50^{* * * *}$, $73.16 \pm 1.01 \% * \%, 58.16 \pm 1.09 *, 42.66 \pm 0.92,27.50 \pm 0.28$, $25.66 \pm 2.18,13.00 \pm 1.15$ and $9.66 \pm 1.33 \%$ activity was 
Table 1 User Chromatogram peaks list for major compounds identified in essential oils from leaves (A) and flowers (B) of Polygonum hydropiper

\begin{tabular}{|c|c|c|c|c|c|c|c|}
\hline RT & Height & Height \% & Area & Area \% & Area Sum \% & Base Peak m/z & Width \\
\hline \multicolumn{8}{|l|}{ A } \\
\hline 14.359 & 11039380 & 39.24 & 27045773 & 17.79 & 6.81 & 81.1 & 0.114 \\
\hline 14.822 & 2441741 & 8.68 & 5347147 & 3.52 & 1.35 & 43.1 & 0.084 \\
\hline 15.505 & 6158002 & 21.89 & 14751160 & 9.7 & 3.72 & 43.1 & 0.111 \\
\hline 16.382 & 4049393 & 14.39 & 10136429 & 6.67 & 2.55 & 93.1 & 0.111 \\
\hline 17.722 & 3399191 & 12.08 & 11251734 & 7.4 & 2.83 & 79.1 & 0.111 \\
\hline 17.839 & 3697087 & 13.14 & 7865419 & 5.17 & 1.98 & 69.1 & 0.084 \\
\hline 18.449 & 26630825 & 94.65 & 144220508 & 94.88 & 36.33 & 79.1 & 0.178 \\
\hline 18.482 & 5054455 & 17.96 & 3502616 & 2.3 & 0.88 & 161.1 & 0.027 \\
\hline 18.663 & 4507537 & 16.02 & 10670668 & 7.02 & 2.69 & 83 & 0.084 \\
\hline 18.951 & 28135093 & 100 & 151997749 & 100 & 38.29 & 109.1 & 0.191 \\
\hline \multicolumn{8}{|l|}{ B } \\
\hline 6.353 & 239671 & 6.66 & 548139 & 4.31 & 1.79 & 68.1 & 0.087 \\
\hline 7.853 & 124166 & 3.45 & 277247 & 2.18 & 0.9 & 43.1 & 0.094 \\
\hline 14.33 & 719035 & 19.97 & 1461208 & 11.5 & 4.76 & 81.1 & 0.077 \\
\hline 16.369 & 196811 & 5.47 & 404002 & 3.18 & 1.32 & 43.1 & 0.07 \\
\hline 16.751 & 181702 & 5.05 & 370460 & 2.91 & 1.21 & 43.1 & 0.074 \\
\hline 18.319 & $3 E+06$ & 71.93 & 5575945 & 43.87 & 18.17 & 43.1 & 0.084 \\
\hline 18.61 & 531433 & 14.76 & 1176145 & 9.25 & 3.83 & 83 & 0.084 \\
\hline 18.821 & $2 E+06$ & 50.77 & 4937507 & 38.84 & 16.09 & 43.1 & 0.124 \\
\hline 19.97 & 959858 & 26.66 & 2359693 & 18.56 & 7.69 & 43.1 & 0.087 \\
\hline 21.433 & $4 E+06$ & 100 & 12711263 & 100 & 41.42 & 43.1 & 0.134 \\
\hline
\end{tabular}

observed for Ph.LO at concentrations of 1000, 800 and 400, 200, 100, 50, 25 and $12.5 \mu \mathrm{g} / \mathrm{ml}$ respectively with $\mathrm{IC}_{50}$ of $180 \mu \mathrm{g} / \mathrm{ml}$. Likewise, Ph.FO exhibited a dose dependent radicals scavenging activity of $87.33 \pm 1.76^{* \% *}$, $78.66 \pm 0.88^{* * * *}, \quad 72.00 \pm 0.86, \quad 66.00 \pm 1.15, \quad 51.33 \pm 0.66$, $45.16 \pm 0.60,38.50 \pm 0.86$ and $30.00 \pm 0.00 \%$ at 1000,800 and $400200,100,50,25$ and $12.5 \mu \mathrm{g} / \mathrm{ml}$ respectively. The $\mathrm{IC}_{50}$ for Ph.FO was $45 \mu \mathrm{g} / \mathrm{ml}$. The standard drug ascorbic acid exhibited $\mathrm{IC}_{50}$ of $45 \mu \mathrm{g} / \mathrm{ml}$ at the same tested concentrations.

\section{Hydrogen peroxide assay}

In $\mathrm{H}_{2} \mathrm{O}_{2}$ radicals scavenging assay, $79.00 \pm 1.00 \% * \%$, $70.66 \pm 0.88, \quad 65.16 \pm 1.96$ and $58.00 \pm 0.28, \quad 47.50 \pm$ $1.04, \quad 42.50 \pm 0.28, \quad 33.16 \pm 1.01$ and $25.66 \pm 0.66 \%$ scavenging effect was observed with Ph.LO at concentrations of 1000, 800, 400, 200, 100, 50, 25 and $12.5 \mu \mathrm{g} / \mathrm{ml}$ respectively. Whereas, Ph.FO showed $77.16 \pm 0.44 * * *, 71.66 \pm 3.17 *, 64.00 \pm 0.00,58.50 \pm 0.76$, $49.83 \pm 0.44, \quad 40.83 \pm 0.92, \quad 32.00 \pm 2.30$ and $21.83 \pm$ $0.60 \%$ inhibitions at concentrations of 1000, 800, $400,200,100,50,25$ and $12.5 \mu \mathrm{g} / \mathrm{ml}$ respectively. The $\mathrm{IC}_{50} \mathrm{~s}$ were 60 and $50 \mu \mathrm{g} / \mathrm{ml}$ for Ph.LO and Ph.FO respectively. In comparison, the standard drug ascorbic acid attain an $\mathrm{IC}_{50}$ of $7 \mu \mathrm{g} / \mathrm{ml}$.

\section{Discussion}

Steam distillation, subsequently GC/MS and GC/FID analysis were used to determine the chemical compositions of essential oils from the leaves and flowers of $P$. hydropiper. Chromatograms with the identified peaks (Fig. 1) as well as the chemical structures of the major identified compounds from leaves and flowers oils are shown in Figs. 2 and 3 respectively. In GC, GC-MS analysis of Ph.LO, 141 compounds were identified among which decahydronaphthalene (38.29\%) was in highest concentration (Fig. 2, Table 1(A)). Likewise, in analysis of Ph.FO, caryophylene oxide $(41.42 \%)$ was present in highest concentration as given in Fig. 3, Table 1(B). The number of identified compounds in Ph.LO were greater than Ph.FO and both anticholinesterase and antioxidant potentials of Ph.LO were observed to be higher than Ph.FO. This is not astonishing that the chemical composition of essential oils greatly depends upon the genetics, age, season and varies with environmental conditions of the plant [34]. Up to the best of our 
<smiles>C=C(C)C1CC=C(C)CC1</smiles>

a<smiles>CC1(C2CCC3(C)OC3C2)CO1</smiles>

d<smiles>CCCCCCCON</smiles>

b<smiles>C=C1CCC2OC2(C)CCC2C1CC2(C)C</smiles>

e<smiles>CC1=CCCC2(C)OC2CC(C)(C)C=CC1</smiles><smiles>C=CC1(C)CCC(C(=C)C)CC1C(=C)C</smiles>

C<smiles>C=C(C)C1CC(C(=C)C)C(C)C(C)(C)C1</smiles>

f

\section{g}

Fig. 3 Major compounds identified in GC-MS analysis of essential oils from flower of Polygonum hydropiper (a) 1-methyl-4-(prop-1-en-2-yl)clohex-1-ene (b) O-Hexylhydroxylamine (c) 1-methyl-2,4-dl(prop-1-en-2-yl)-1-vinylcyclohexane (d) 1-methyl-4-(2-methyloiran-2-yl)-7-oxa-bicyclo(4.1.0)heptane (e) (-)-B-Caryophylleneepoxide (f) 1,1,2-trimethyl-3,5-di(prop-1-en-2-yl)cycloheaxane (g) (4E,7E)-1,5,9,9-tetramethyl-12-oxabicyclo[9.1.0]dodeca-4,7-diene

knowledge this is the most detailed report on the chemical composition of essential oils from P. hydropiper.

Acetylcholinesterase (AChE) and butyrylcholinesterase $(\mathrm{BChE})$ are the key enzymes catalyzing the breakdown of the important neurotransmitter acetylcholine $(\mathrm{ACh})$ in the nervous system to form acetate and choline [25]. ACh insufficiency in the cerebral cortex of humans is among the vital pathophysiologies observed in $\mathrm{AD}$ patients $[35,36]$. An important tool for treating $\mathrm{AD}$ is to boost the level of $\mathrm{ACh}$ in the brain by the administration of safe and effective AChE inhibitors [37]. Among the clinically approved drugs, four are cholinesterase inhibitors including tacrine, donepezil, rivastigmine and galantamine, whereas, the fifth one is glutamatergic system modifier called memantine (Fig. 4). Among these four drugs, the use of tacrine is limited due to hepatotoxic effects associated with it [38, 39]. Further, studies during clinical trials revealed that cholinesterase inhibitors may help AD patients to sustain their ability to perform routine activities with less frequent behavioral changes [40]. Other studies suggest that cholinesterase inhibitors may improve the cognitive performance of the AD patients even in the advanced stages of the disease [41]. Consequently, cholinesterase inhibitors may improve cognitive decline and thus reduce the emergence of new behavioral turbulence.
In the current study, we observed that Ph.LO were most effective against AChE causing $87.00 \pm 1.15 \%$ inhibition followed by Ph.FO with $79.66 \pm 0.88 \%$ enzyme inhibition at $1000 \mu \mathrm{g} / \mathrm{ml}$. Among both oils, Ph.LO was more potent with $\mathrm{IC}_{50}$ of $120 \mu \mathrm{g} / \mathrm{ml}$, while the $\mathrm{IC}_{50}$ for Ph.FO was $220 \mu \mathrm{g} / \mathrm{ml}$. The $\mathrm{IC}_{50}$ value for galanthamine was $15 \mu \mathrm{g} / \mathrm{ml}$. Both oils exhibited concentration dependent activity as shown in Table 2. In BChE inhibitory assay, again Ph.LO was more active causing $82.66 \pm 1.20 \%$ inhibition at $1000 \mu \mathrm{g} / \mathrm{ml}$ and $\mathrm{IC}_{50}$ of $130 \mu \mathrm{g} / \mathrm{ml}$. Moreover, Ph.FO revealed $77.50 \pm 0.44 \%$ inhibition at the same concentration with $\mathrm{IC}_{50}$ of $225 \mu \mathrm{g} / \mathrm{ml}$. Positive control inhibition was $96.00 \pm 1.52 \%$ at the same concentration and $\mathrm{IC}_{50}$ was $10 \mu \mathrm{g} / \mathrm{ml}$. Presently, there is no complete preventative or curative drug therapy available for $\mathrm{AD}$, leaving the symptomatic relief presented by $\mathrm{AChE} / \mathrm{BChE}$ inhibitors as the single approved therapeutic choice. Recently, galanthamine from Amaryllidaceae family is approved for clinical use and has become a vital therapeutic option effective to retard the process of neurological degeneration in $\mathrm{AD}$. Galanthamine provides an efficient symptomatic therapy for $\mathrm{AD}$ patients and also delay the progression of the disease. Another isoquinoline alkaloid berberine, isolated from Rhizoma coptidis and Cortex phellodendri is reported as an effective neuroprotective agent in diseases 
Table 2 Results of AChE and BChE inhibitory activity of essential oils from leaves and flowers of Polygonum hydropiper

\begin{tabular}{|c|c|c|c|c|c|c|}
\hline \multirow[t]{2}{*}{ Sample } & \multicolumn{3}{|c|}{$\%$ AChE inhibition Mean \pm SEM $(n=3)$} & \multicolumn{3}{|c|}{$\%$ BChE inhibition Mean \pm SEM $(n=3)$} \\
\hline & Concentration & $\%$ inhibition & $\mathrm{I}_{50}$ & Concentration & $\%$ inhibition & $\mathrm{I}_{50}$ \\
\hline \multirow[t]{8}{*}{ Essential oils from leaves (Ph.Lo) } & 12.5 & $28.00 \pm 0.57^{* * *}$ & \multirow[t]{8}{*}{120} & 12.5 & $20.66 \pm 1.20^{* * *}$ & \multirow[t]{8}{*}{130} \\
\hline & 25 & $36.50 \pm 0.44^{* * *}$ & & 25 & $31.00 \pm 1.15^{* * *}$ & \\
\hline & 50 & $44.66 \pm 1.20^{* * *}$ & & 50 & $40.33 \pm 0.88^{* * *}$ & \\
\hline & 100 & $52.00 \pm 1.52^{* * *}$ & & 100 & $48.66 \pm 1.20^{* * *}$ & \\
\hline & 125 & $57.33 \pm 0.88^{* * *}$ & & 125 & $52.00 \pm 0.57^{* * *}$ & \\
\hline & 250 & $63.66 \pm 0.33^{* * *}$ & & 250 & $61.00 \pm 1.15^{* * *}$ & \\
\hline & 500 & $71.00 \pm 0.57^{* * *}$ & & 500 & $70.66 \pm 0.88^{* * *}$ & \\
\hline & 1000 & $87.00 \pm 1.15^{* *}$ & & 1000 & $82.66 \pm 1.20^{* * *}$ & \\
\hline \multirow[t]{8}{*}{ Essential oils from flowers (Ph.Fo) } & 12.5 & $21.66 \pm 0.66^{* * *}$ & \multirow[t]{8}{*}{220} & 12.5 & $18.00 \pm 0.57^{* * *}$ & \multirow[t]{8}{*}{225} \\
\hline & 25 & $28.00 \pm 1.15^{* * *}$ & & 25 & $23.00 \pm 1.15^{* * *}$ & \\
\hline & 50 & $35.00 \pm 0.57^{* * *}$ & & 50 & $27.33 \pm 0.33^{* * *}$ & \\
\hline & 100 & $43.33 \pm 1.45^{* * *}$ & & 100 & $35.00 \pm 0.16^{* * *}$ & \\
\hline & 125 & $49.00 \pm 0.00^{* * *}$ & & 125 & $46.66 \pm 1.20^{* * *}$ & \\
\hline & 250 & $55.00 \pm 1.00^{* * *}$ & & 250 & $53.66 \pm 0.88^{* * *}$ & \\
\hline & 500 & $61.66 \pm 1.20^{* * *}$ & & 500 & $64.00 \pm 0.00^{* * *}$ & \\
\hline & 1000 & $79.66 \pm 0.88^{* * *}$ & & 1000 & $77.50 \pm 0.44^{* * *}$ & \\
\hline \multirow[t]{8}{*}{ Galanthamine (P. Control) } & 12.5 & $51.00 \pm 0.00$ & \multirow[t]{8}{*}{15} & 12.5 & $60.00 \pm 0.57$ & \multirow[t]{8}{*}{10} \\
\hline & 25 & $60.50 \pm 0.44$ & & 25 & $70.00 \pm 1.52$ & \\
\hline & 50 & $65.66 \pm 0.33$ & & 50 & $77.66 \pm 1.20$ & \\
\hline & 100 & $72.00 \pm 2.64$ & & 100 & $81.00 \pm 0.00$ & \\
\hline & 125 & $77.00 \pm 0.00$ & & 125 & $86.66 \pm 1.76$ & \\
\hline & 250 & $83.33 \pm 0.66$ & & 250 & $89.33 \pm 1.45$ & \\
\hline & 500 & $87.00 \pm 1.20$ & & 500 & $92.33 \pm 0.66$ & \\
\hline & 1000 & $92.33 \pm 0.33$ & & 1000 & $96.00 \pm 1.52$ & \\
\hline
\end{tabular}

Results were expressed as means \pm S.E.M. The $P$ values less than 0.05 were considered as statistically significant. Values significantly different when compared to slandered drug (Galanthamine) at the same concentration i.e. ${ }^{*}: P<0.05,{ }^{* *}: P<0.01$ and ${ }^{* * *}: P<0.001$

like cerebral ischemia, schizophrenia, AD, depression and anxiety [42, 43]. Berberine is reported to reduce extracellular $A \beta$ fabrication and BACE activity without affecting the release of $\mathrm{LDH}$ in $\mathrm{H} 4$ neuroglioma (APPNL-H4) cells [8]. Berberine therapy also reduces cognitive dysfunction as indicated by decrease in errors using MWM task in comparison to usual reference memory and memory retention (probe trial) in APP transgenic mice. [44]. The essential oils in the current study exhibited comparative percent inhibitions with the standard drug in both assays. However, the $\mathrm{IC}_{50}$ of essential oils were higher than that of an orally administered standard drug galanthamine. We speculate that the essential oils administered in the form of vapors (aerosol) will have better availability than orally administered drugs due to high lipid solubility and bypassing presystemic metabolism. However, further in-vivo studies on genetically modified animals' models are required to confirm its in-vivo bioavailability and potential efficacy in neurological disorders.
Modern research revealed that beta secretase enzyme (BACE1) catalyze the breakdown of amyloid precursor protein (APP) to form ß-amyloid peptides in $\mathrm{AD}$ brain, which provoke inflammatory process with consequent release of free radicals oxygen species causing neuronal damage [45-47]. Antioxidant drugs may contribute to $\mathrm{AD}$ chemotherapy by attenuation of the inflammatory pathways via scavenging of free radicals [37]. In recent times, natural products has got more attention as antioxidants as they are safer and these substances could be supplied as food components or in the form of pharmaceuticals for human use [48]. Among those, essential oils from aromatic and medicinal plants are well known to reveal antioxidant and cholinesterase inhibitory properties and thus can be very helpful in the treatment of $A D$ [49]. In DPPH assay, Ph.LO was most effective causing $85.00 \pm 1.15, \quad 79.50 \pm 0.28$ and $72.00 \pm 1.04 \%$ free radicals scavenging at concentrations of 1000 , 800 and $400 \mu \mathrm{g} / \mathrm{ml}$ respectively. DPPH free radicals 
Table 3 Antioxidant Potential of essential oils from Polygonum hydropiper leaves and flowers

\begin{tabular}{|c|c|c|c|c|c|c|c|}
\hline \multirow[t]{2}{*}{ Samples } & \multicolumn{3}{|c|}{ DPPH free radical scavenging } & \multicolumn{2}{|c|}{ ABTS free radical scavenging } & \multicolumn{2}{|c|}{$\underline{\mathrm{H}_{2} \mathrm{O}_{2} \text { free radical scavenging }}$} \\
\hline & Conc. $\mu \mathrm{g} / \mathrm{ml}$ & $\%$ inhibition & $\mathrm{I}_{50}$ & $\%$ inhibition & $\mathrm{IC}_{50}$ & $\%$ inhibition & $\mathrm{IC}_{50}$ \\
\hline \multirow[t]{8}{*}{ Essential oils from leaves (Ph.LO) } & 12.5 & $37.95 \pm 0.29^{* * *}$ & \multirow[t]{8}{*}{20} & $9.66 \pm 1.33^{\text {ns }}$ & \multirow[t]{8}{*}{180} & $25.66 \pm 0.66^{\mathrm{ns}}$ & \multirow[t]{8}{*}{60} \\
\hline & 25 & $46.66 \pm 0.72^{\mathrm{ns}}$ & & $13.00 \pm 1.15^{\mathrm{ns}}$ & & $33.16 \pm 1.01^{\mathrm{ns}}$ & \\
\hline & 50 & $53.50 \pm 0.86^{\mathrm{ns}}$ & & $25.66 \pm 2.18^{\mathrm{ns}}$ & & $42.50 \pm 0.28^{\mathrm{ns}}$ & \\
\hline & 100 & $60.66 \pm 0.92^{*}$ & & $27.50 \pm 0.28^{n s}$ & & $47.50 \pm 1.04^{\mathrm{ns}}$ & \\
\hline & 200 & $65.16 \pm 0.60^{*}$ & & $42.66 \pm 0.92^{\mathrm{ns}}$ & & $58.00 \pm 0.28^{n s}$ & \\
\hline & 400 & $72.00 \pm 1.04^{* * *}$ & & $58.16 \pm 1.09^{*}$ & & $65.16 \pm 1.96^{\mathrm{ns}}$ & \\
\hline & 800 & $79.50 \pm 0.28^{* * *}$ & & $73.16 \pm 1.01^{* * *}$ & & $70.66 \pm 0.88^{\mathrm{ns}}$ & \\
\hline & 1000 & $85.00 \pm 1.15^{* *}$ & & $89.00 \pm 0.50^{* * *}$ & & $79.00 \pm 1.00^{* * *}$ & \\
\hline \multirow[t]{8}{*}{ Essential oils from Flower (Ph.FO) } & 12.5 & $22.83 \pm 0.72^{* * *}$ & \multirow[t]{8}{*}{200} & $30.00 \pm 0.00^{\mathrm{ns}}$ & \multirow[t]{8}{*}{45} & $21.83 \pm 0.60^{\mathrm{ns}}$ & \multirow[t]{8}{*}{50} \\
\hline & 25 & $28.00 \pm 0.57^{* * *}$ & & $38.50 \pm 0.86^{\mathrm{ns}}$ & & $32.00 \pm 2.30 \mathrm{~ns}$ & \\
\hline & 50 & $35.83 \pm 0.60^{* * *}$ & & $45.16 \pm 0.60^{\mathrm{ns}}$ & & $40.83 \pm 0.92^{\mathrm{ns}}$ & \\
\hline & 100 & $42.33 \pm 0.44^{* * *}$ & & $51.33 \pm 0.66^{\mathrm{ns}}$ & & $49.83 \pm 0.44^{\mathrm{ns}}$ & \\
\hline & 200 & $47.33 \pm 1.30^{* * *}$ & & $66.00 \pm 1.15^{\mathrm{ns}}$ & & $58.50 \pm 0.76^{\mathrm{ns}}$ & \\
\hline & 400 & $54.83 \pm 2.92^{* * *}$ & & $72.00 \pm 0.86^{\mathrm{ns}}$ & & $64.00 \pm 0.00 \mathrm{~ns}$ & \\
\hline & 800 & $70.16 \pm 0.60^{* * *}$ & & $78.66 \pm 0.88^{* * * *}$ & & $71.66 \pm 3.17^{*}$ & \\
\hline & 1000 & $81.33 \pm 0.72^{* * *}$ & & $87.33 \pm 1.76^{* * *}$ & & $77.16 \pm 0.44^{* * *}$ & \\
\hline \multirow[t]{8}{*}{ Ascorbic Acid (Positive control) } & 12.5 & $45.00 \pm 0.50$ & \multirow[t]{8}{*}{5} & $49.16 \pm 0.60$ & \multirow[t]{8}{*}{10} & $46.66 \pm 0.72$ & \multirow[t]{8}{*}{7} \\
\hline & 25 & $47.33 \pm 1.30$ & & $56.50 \pm 1.04$ & & 55. $16 \pm 0.60$ & \\
\hline & 50 & $54.88 \pm 1.30$ & & $63.16 \pm 1.01$ & & $63.00 \pm 0.00$ & \\
\hline & 100 & $63.00 \pm 1.15$ & & $70.00 \pm 0.00$ & & $68.58 \pm 0.69$ & \\
\hline & 200 & $68.36 \pm 0.57$ & & $75.45 \pm 0.65$ & & $71.44 \pm 0.58$ & \\
\hline & 400 & $79.85 \pm 2.24$ & & $81.37 \pm 0.64$ & & $76.45 \pm 0.77$ & \\
\hline & 800 & $87.08 \pm 0.47$ & & $88.37 \pm 0.54$ & & $84.36 \pm 0.64$ & \\
\hline & 1000 & $91.90 \pm 0.96$ & & $94.30 \pm 0.61$ & & $89.37 \pm 0.65$ & \\
\hline
\end{tabular}

Each value represent mean \pm S.E.M of three independent experimental results. Values significantly different when compared to slandered drug (Ascorbic acid) at the same concentration i.e. *: $P<0.05,{ }^{* *}: P<0.01$ and ${ }^{* *}$ : $P<0.001$. ns: Values not significantly different in comparison to $P$. control

scavenging activity of Ph.FO was $81.33 \pm 0.72,70.16 \pm$ 0.60 and $54.83 \pm 2.92 \%$ at 1000,800 and $400 \mu \mathrm{g} / \mathrm{ml}$ respectively. Ph.LO and Ph.FO exhibited $\mathrm{IC}_{50}$ of 20 and $200 \mu \mathrm{g} / \mathrm{ml}$ respectively, whereas, the $\mathrm{IC}_{50}$ of ascorbic acid was $5 \mu \mathrm{g} / \mathrm{ml}$ (Table 3). Likewise, In ABTS assay Ph.LO demonstrated $89.00 \pm 0.50 \%$ inhibitions of free radicals followed by Ph.FO with $87.33 \pm 1.76 \%$ inhibition at $1000 \mu \mathrm{g} / \mathrm{ml}$. All fractions showed concentration dependent activity. For both samples, the $\mathrm{IC}_{50}$ values were 180 and $45 \mu \mathrm{g} / \mathrm{ml}$ respectively. In $\mathrm{H}_{2} \mathrm{O}_{2}$ free radicals scavenging assay, $79.00 \pm 1.00$ and $77.16 \pm 0.44 \%$ inhibitions were observed for Ph.LO and Ph.FO respectively at $1000 \mu \mathrm{g} / \mathrm{ml}$. For these samples the $\mathrm{IC}_{50}$ were 60 and $50 \mu \mathrm{g} / \mathrm{ml}$. Ph.LO was observed to be more effective against all tested free radicals. In both assays Ph.LO was more effective in comparison to Ph.FO which can be attributed to the presence of active compounds in Ph.LO. In the current study, the percent inhibitions of essential oils were comparative to standard drugs at the same concentrations. Though the $\mathrm{IC}_{50}$ of oils were higher than standard drugs, still the dual efficacy (anticholinesterase and antioxidant) of essential oils demonstrate their potential effectiveness in neurological disorders.

\section{Conclusions}

Essential oils from $P$. hydropiper were investigated for the first time for anticholinesterase and antioxidant potentials. All samples exhibited concentration dependent enzyme inhibitions and anti-radical activities with Ph.LO most affective. In GC, GC-MS analysis 144 and 122 compounds were identified in Ph.LO and Ph.FO respectively. Further in-vivo studies are required for possible use of these samples in neurodegenerative disorders.

\section{Material and methods}

Collection of plant material

Fresh leaves of $P$. hydropiper were collected from Talash Valley Dir (L) Pakistan in the month of September 2014. 


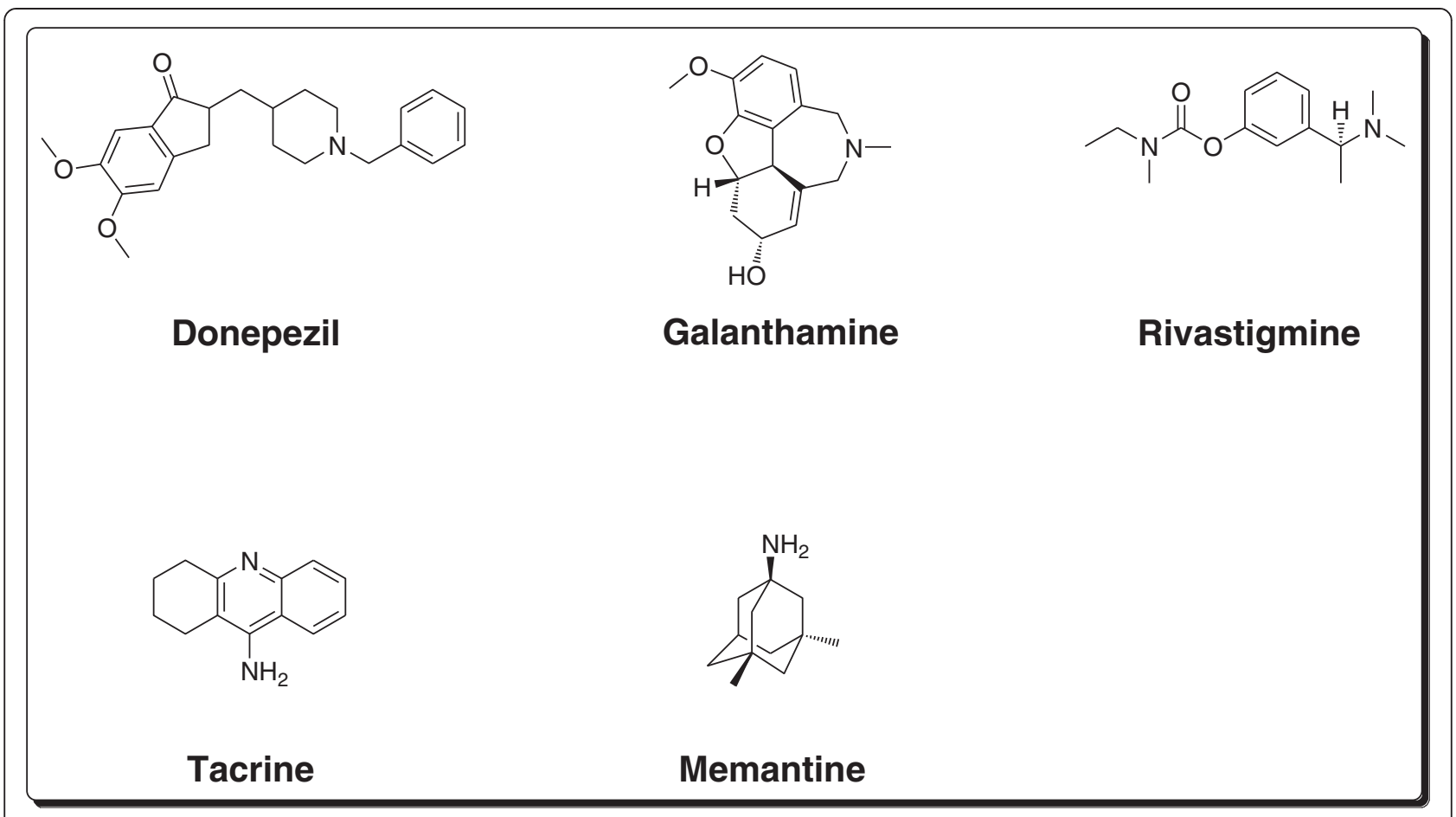

Fig. 4 Clinically available drugs for Alzheimer's therapy

The leaves were washed with distilled water to remove any dust. Whereas, flowers of $P$. hydropiper were in full bloom in the month of September 2014, in Talash valley Dir lower Pakistan and were collected. Plant samples were deposited at the herbarium, University of Malakand Chakdara (Dir), Pakistan with voucher no (H.UOM.BG.107).

\section{Isolation of the essential oils}

Fresh leaves of $P$. hydropiper were macerated and hydrodistilled using a Clevenger type apparatus supplied with condenser. Distillation process was continued for 3 days at $100{ }^{\circ} \mathrm{C}$, and the volatile oils (yellowish in color) were collected in glass bottles. Anhydrous sodium sulfate was used to remove water after extraction [50]. Flowers of $P$. hydropiper were hydro-distilled with a Likens-Nickerson-type apparatus using diethyl ether for $3 \mathrm{~h}$. White to yellow color obtained which was dried over anhydrous sodium sulphate. Finally, the oils were properly sealed in glass vials and stored in refrigerator at $-30{ }^{\circ} \mathrm{C}$ before further analysis.

\section{Gas chromatography (GC) analysis}

Essential oils samples were analyzed by means of an Agilent USB-393752 gas chromatograph (Agilent Technologies, Palo Alto, CA, USA) with HHP-5MS $5 \%$ phenylmethylsiloxane capillary column $(30 \mathrm{~m} \times 0.25 \mathrm{~mm}$ $\times 0.25 \mu \mathrm{m}$ film thickness; Restek, Bellefonte, PA) equipped with an FID detector. The temperature of Oven was maintained at $70{ }^{\circ} \mathrm{C}$ for $1 \mathrm{~min}$ at first, and then increased at the rate of $6{ }^{\circ} \mathrm{C} / \mathrm{min}$ to $180{ }^{\circ} \mathrm{C}$ for $5 \mathrm{~min}$ and lastly at the rate of $5{ }^{\circ} \mathrm{C} / \mathrm{min}$ to $280{ }^{\circ} \mathrm{C}$ for $20 \mathrm{~min}$. Injector and detector temperatures were set at $220{ }^{\circ} \mathrm{C}$ and $290{ }^{\circ} \mathrm{C}$, correspondingly. Helium was used as carrier gas at a flow rate of $1 \mathrm{ml} / \mathrm{min}$, and diluted samples $(1 / 1000$ in $n$-pentane, $v / v)$ of $1.0 \mu \mathrm{l}$ were injected manually in the split-less mode.

Gas chromatography-mass spectrometry (GC/MS) analysis GC/MS analysis of the oil samples were processed using an Agilent USB-393752 gas chromatograph (Agilent Technologies, Palo Alto, CA, USA) with a HHP-5MS $5 \%$ phenylmethylsiloxane capillary column $(30 \mathrm{~m} \times$ $0.25 \mathrm{~mm} \times 0.25 \mu \mathrm{m}$ film thickness; Restek, Bellefonte, PA) outfitted with an Agilent HP-5973 mass selective detector in the electron impact mode (Ionization energy: $70 \mathrm{eV}$ ) working under the same experimental conditions as described for GC.

\section{Identification of components}

Oils major constituents were recognized by comparison of their retention times with those of authentic compounds in the literature. Moreover, identification was done via the spectral data obtained from the Wiley and NIST libraries, as well as comparisons of 
the fragmentation pattern of the mass spectra with data published in the literature $[51,52]$ or with mass spectra from literature.

\section{Chemical and drugs}

For cholinesterase inhibition assay, AChE from Electric eel (type-VI-S, code 1001596210) and BChE from equine serum Lyophilized (code 101292670) were purchased from Sigma-Aldrich GmbH USA. Enzyme substrates including acetylthiocholine iodide (code 101303874) and butyrylthiocholine Iodide (code 101334643) were purchased from Sigma-Aldrich UK and Sigma-Aldrich Switzerland respectively. Indicator substance, 5,5-dithiobis-nitrobenzoic acid (DTNB) code 101261619 was purchased from Sigma-Aldrich Germany. Standard drug galanthamine hydrobromide Lycoris Sp. (code G1660) was purchased from Sigma-Aldrich France. For antioxidant assays, DPPH (code 101341986 Sigma Aldrich CHEMIE GmbH USA), ABTS (code 1001551916 Sigma Aldrich USA), $\mathrm{K}_{2} \mathrm{~S}_{2} \mathrm{O}_{4}$ (Riedel-de Haen Germany) and Folin Ciocalteu reagent (FCR) were acquired from Merck Co. (Germany). Buffer system including $\left(\mathrm{K}_{2} \mathrm{HPO}_{4}\right),\left(\mathrm{KH} 2 \mathrm{PO}_{4}\right)$, $\mathrm{KOH}$ and solvents used were of extra pure quality.

\section{Anticholinesterase assays}

$\mathrm{AChE}$ and BChE inhibitory potentials of the samples were carried out following Ellman's assay [53, 54]. Using this procedure, acetylthiocholine iodide or butyrylthiocholine iodide are hydrolyzed by the respective enzymes to form 5-thio-2-nitrobenzoate anion which then form complex with DTNB and give UV detectable yellow color compound.

\section{Preparation of solutions}

Oil samples were dissolved in phosphate buffer (0.1 M) in concentrations of 12.5, 25, 50, 100, 125, 500 and $1000 \mu \mathrm{g} / \mathrm{ml}$. Phosphate buffer $(0.1 \mathrm{M}$ with $8.0 \pm 0.1 \mathrm{pH})$ was prepared by mixing $\mathrm{K}_{2} \mathrm{HPO}_{4}$ $(17.4 \mathrm{~g} / \mathrm{L})$ and $\mathrm{KH}_{2} \mathrm{PO}_{4}(13.6 \mathrm{~g} / \mathrm{L})$ solution in a ratio of $94 \%$ and $6 \%$ respectively. $\mathrm{pH}$ was adjusted using potassium hydroxide. To prepare enzyme solutions, $\mathrm{AChE}(518 \mathrm{U} / \mathrm{mg}$ solid) and $\mathrm{BChE}(7-16 \mathrm{U} / \mathrm{mg})$ were diluted in buffer solution ( $\mathrm{pH}$ 8.0) up to final concentrations of $0.03 \mathrm{U} / \mathrm{ml}$ and $0.01 \mathrm{U} / \mathrm{ml}$. Substrate solutions including ATchI, BTchI $(0.0005 \mathrm{M})$ and DTNB $(0.0002273 \mathrm{M})$, were prepared using distilled water and were refrigerated at $8{ }^{\circ} \mathrm{C}$ until use. Standard drug (galanthamine) dilutions were made in methanol.

\section{Spectroscopic analysis}

In each experiment, $5 \mu \mathrm{l}$ enzyme solutions were added to the cuvette and oil samples were added at the above mentioned concentrations. Finally, DTNB reagent $(5 \mu \mathrm{l})$ was added to the cuvette and the resultant mixture was incubated at $30{ }^{\circ} \mathrm{C}$ for 15 min using water bath. A substrate solution $(5 \mu \mathrm{l})$ was added at the end and absorbance was measured at $412 \mathrm{~nm}$ using a double beam spectrophotometer (Thermo electron corporation USA). Negative control contained all components except oil samples, while positive control galanthamine $(10 \mu \mathrm{g} /$ $\mathrm{ml}$ ) was used in the assay as standard cholinesterase inhibitor. Change in absorbance along with the reaction time was recorded for $4 \mathrm{~h}$ at $30{ }^{\circ} \mathrm{C}$. The experiments were performed in triplicate. Enzymes activity and enzyme inhibition by control and tested samples were determined from the rate of absorption with change in time $(V=\Delta \mathrm{Abs} / \Delta \mathrm{t})$ as; Enzyme inhibition $(\%)=100$ - percent enzyme activity;

$$
\text { Enzyme activity }(\%)=\frac{100 \times \mathrm{V}}{\mathrm{V}_{\max }}
$$

Where $\left(\mathrm{V}_{\max }\right)$ is enzyme activity in the absence of inhibitor drug.

\section{Antioxidant assays DPPH free radicals scavenging assay}

Free radicals scavenging ability of the essential oil was determined following well established procedures $[29,55]$. Different dilutions $(12.5,50,100,200,400$, 800 and $1000 \mu \mathrm{g} / \mathrm{ml})$ of essential oils $(0.1 \mathrm{ml})$ were added to $0.004 \%$ methanolic solution of DPPH. After $30 \mathrm{~min}$, absorbance was measured at $517 \mathrm{~nm}$ using UV spectrophotometer (Thermo electron corporation, USA). Percent DPPH scavenging activity was calculated as;

$$
\frac{\mathrm{A}_{0}-\mathrm{A}_{1}}{\mathrm{~A}_{0}} \times 100
$$

Ascorbic acid was used as positive control. Where $\mathrm{A}_{0}$ characterize absorbance of control and $A_{1}$ is the absorbance of the essential oils. All experiments were performed in triplicate and inhibition graphs were made with the help of GraphPad prism program (GraphPAD, San Diego, California, USA). Median inhibitory concentrations $\mathrm{IC}_{50}$ values were calculated using Microsoft Excel programme.

\section{ABTS free radicals scavenging assay}

The ABTS free radical scavenging potential of samples were evaluated using previously reported procedure [56]. The test is based on the ability of antioxidants present in the sample to scavenge ABTS radicals leading to reduction. Using this procedure, solutions of ABTS $7 \mathrm{mM}$ and potassium persulphate $\left(\mathrm{K}_{2} \mathrm{~S}_{2} \mathrm{O}_{4}\right) 2.45 \mathrm{mM}$ were mixed and stored in dark place at room temperature for $12-16 \mathrm{~h}$ to obtain a dark colored solution. This solution was diluted using Phosphate buffer $(0.01 \mathrm{M}) \mathrm{pH} 7.4$ and absorbance 
value was adjusted to 0.70 at $734 \mathrm{~nm}$. Finally, $300 \mu \mathrm{l}$ solution of test sample was added to $3.0 \mathrm{ml}$ of ABTS solution in cuvette and was analyzed spectrophotometerically at $734 \mathrm{~nm}$. The decline in absorbance was determined after one minute of mixing the solutions and analysis was continued for $6 \mathrm{~min}$. Ascorbic acid was used as positive control. The assay was repeated in triplicate and percentage inhibition was calculated using formula:

$\%$ scavenging effect $=$ control absorbance sample absorbance /control absorbance $\times 100$

\section{Hydrogen peroxide free radicals scavenging assay}

The hydrogen peroxide scavenging activity of extracts was determined using methods described previously [57]. Using this method $2 \mathrm{mM}$ hydrogen peroxide solution was prepared in $50 \mathrm{mM}$ phosphate buffer having $\mathrm{pH}$ of 7.4. Oil samples $(0.1 \mathrm{ml})$ were taken in test tubes and their volumes were increased to $0.4 \mathrm{ml}$ using $50 \mathrm{mM}$ phosphate buffer solution. Hydrogen peroxide $(0.6 \mathrm{ml})$ was added to the tubes and was vertexed. Absorbance of each sample was measured at $230 \mathrm{~nm}$ against the blank after $10 \mathrm{~min}$. Hydrogen peroxide scavenging activity was calculated using equation;

\section{$\frac{1 \text {-absorbance of sample }}{\text { Absorbance of control }} \times 100$}

\section{Estimation of $\mathrm{IC}_{50}$ values}

Concentrations of the oils which inhibited substrate hydrolysis (AChE and $\mathrm{BChE}$ ) by $50 \%\left(\mathrm{IC}_{50}\right)$ were calculated from dose response ratio using Microsoft Excel program. In $\mathrm{DPPH}, \mathrm{ABTS}$ and $\mathrm{H}_{2} \mathrm{O}_{2}$ the $\mathrm{IC}_{50}$ values were calculated using the same procedure.

\section{Statistical data analysis}

All the assays were repeated in triplicate and values were expressed as mean \pm S.E.M. One way ANOVA followed by Dunnett's multiple comparison test was applied for the comparison of positive control with the test group at $95 \%$ confidence interval using GraphPad prism Software USA. The $P$ values less than 0.05 were considered as statistically significant.

\section{Additional files}

Additional file 1: Table S1. Details of compounds identified in GC, GC-MS analysis of essential oils from leaves of Polygonum hydropiper. (DOCX $29 \mathrm{~kb}$ )

Additional file 2: Table S2. Details of compounds identified in GC, GC-MS analysis of essential oils from flowers of Polygonum hydropiper. (DOCX $28 \mathrm{~kb}$ )

\section{Competing interests}

The authors declare that they have no competing interests.

\section{Author's contributions}

MA carried out experimental work, data collection and evaluation, literature search and manuscript preparation. MJ and FU supervised research work. SA helped in experiments. MAK, AS and WA Helped in study design and refined the manuscript for publication. MRS and MI conducted GC, GC-MS. All authors read and approved the final manuscript for publication.

\section{Acknowledgements}

The authors sincerely thank Dr. Gul Rahim for identification of the plant. The authors also want to thank University of Malakand and University of Karachi for providing laboratory facilities to conduct experiments and GC, GC-MS analysis respectively.

\section{Funding}

This research received no specific grant from any funding agency in the public, commercial, or not-for-profit sectors.

\section{Author details}

${ }^{1}$ Department of Pharmacy, University of Malakand, Khyber pakhtoonkhwa (KPK) 18000, Pakistan. ${ }^{2}$ H.E. J. Research Institute of Chemistry, International Center for Chemical and Biological Sciences, University of Karachi, Karachi 75270, Pakistan.

Received: 28 August 2015 Accepted: 27 October 2015

Published online: 04 November 2015

\section{References}

1. Davies P, Maloney A. Selective loss of central cholinergic neurons in Alzheimer's disease. Lancet. 1976;2:1403.

2. Perry E. The cholinergic hypothesis - ten years on. Br Med Bull. 1986;42:63-9.

3. Thomsen $\mathrm{T}$, Kewitz $\mathrm{H}$. Selective inhibition of human acetylcholinesterase by galanthamine in-vitro and in-vivo. Life Sci. 1990;46:553-1558.

4. Sugimoto $H$, limura $Y$, Yamanishi $Y$, Yamatsu K. Synthesis and structureactivity relationships of acetylcholinesterase inhibitors:1-benzyl-4-[(5,6dimethoxy-1-oxoindan-2-yl)methyl] piperidine hydrochloride and related compounds. J Med Chem. 1995;38:4821-9.

5. Raskind M, Peskind E, Wessel T, Yuan W. Galantamine in AD: A 6-month randomised, placebo-controlled trial with a 6-month extention. The Galantamine USA-1 Study Group. Neurology. 2000;54:2261-8.

6. Rogers S, Farlow M, Doody R, Mohs R, Friedhoff LT. A 24-week, doubleblind, placebo-controlled trial of donepezil in patients with Alzheimer's disease. Donepezil Study Group. Neurology. 1998;50:136-45.

7. Rösler M, Anand R, Cicin-Sain A, Gauthier S, Agid Y, Dal-Bianco P, et al. Efficacy and safety of rivastigmine in patients with Alzheimer's disease: inter-national randomised controlled trial. Br Med J. 1999;318(7184):633-8.

8. Ballard C. Advances in the treatment of Alzheimer's disease: benefits of dual cholinesterase inhibition. Eur Neurol. 2001;47:64-70

9. Greig N, Utsuki T, Yu Q. A new therapeutic target in Alzheimer's disease treatment: attention to butyrylcholinesterase. Curr Med Res Opin. 2001;17:1-6.

10. Soreq $\mathrm{H}$, Zaku H. Human cholinesterases and anti-cholinesterases. New York: Academic; 1993.

11. Wright C, Geula C, Mesulam M. Neurological choline-sterases in the normal brain and in Alzheimer's disease: relationship to plaques, tangles and patterns of selective vulnerability. Ann Neurol. 1993;34:373-84.

12. Mesulam M, Guillozet A, Shaw P, Levey A, Duysen E, Lockridge O. Acetylcholinesterase knockouts establish central pathways and can use butyrylcholinesterase to hydrolyse acetylcholine. Neuroscience. 2002;110:627-39

13. Perry E, Perry R, Blessed G, Tomlinson B. Changes in brain cholinesterases in senile dementia of Alzheimer's type. Neuropathol Appl Neurobiol. 1978:4:273-7.

14. Giacobini E, Spiegel R, Enz A, Veroff A, Cutler N. Inhibition of acetyl and butyryl-cholinesterases in the cerebrospinal fluid of patients with Alzheimer's disease by rivastigmine: correlation with cognitive benefit. J Neural Transm. 2002;109(7-8):1053-65.

15. Giacobini E, Griffini P, Maggi T. The effect of MF8622, a selective butyrylcholinesterase inhibitor on cortical levels of acetylcholine. San Diego: Society for Neuroscience Annual Meeting; 1995. 
16. Knapp MJ, Knopman DS, Solomon PR, Pendlebury WW, Davis CS, Gracon SI. A 30-week randomized controlled trial of high-dose tacrine in patients with Alzheimer's disease.The Tacrine study group. JAMA, J Am Med Assoc. 1994;271(13):985-91.

17. Schneider $L$. Treatment of Alzheimer's disease with cholinesterase inhibitors. Clin Geriatr Med. 2001:17(2):337-58.

18. Heinrich M, Teoh HL. Galanthamine from snowdrop-the development of a modern drug against Alzheimer's disease from local Caucasian knowledge. J Ethnopharmacol. 2004;92:147-62.

19. Perry NSL, Houghton PJ, Theobald A, Jenner P, Perry EK. In-vitro inhibition of human erythrocyte acetylcholinesterase by Salvia lavandulaefolia essential oil and constituent terpenes. J Pharm Pharmacol. 2000;52:895-902.

20. Breinholt $\mathrm{V}$, Kumpulainen JT, Salonen JT. Natural antioxidants and anticarcinogens in nutrition, health and disease.Eds. JT Kumpulainen and JT Salonen. Royal Society of Chemistry. Cambridge: 1999.

21. Shah SM, Ayaz M, Khan A-u, Ullah F, Farhan, Shah A-u-HA, Iqbal H, Hussain S. 1,1-Diphenyl,2-picrylhydrazyl free radical scavenging, bactericidal, fungicidal and leishmanicidal properties of Teucrium stocksianum. Toxicol Ind Health. 2013. DOl: 10.1177/0748233713487250.

22. Halliwell B. Free radicals, antioxidants, and human disease: curiosity, cause, or consequence? Lancet. 1994;344(8924):721-4.

23. Henry W, Querfurth HW, LaFerla FM. Mechanisms of disease Alzheimer's disease. New Engl J Med. 2010;362:329-44.

24. Barlow SM. Toxicological aspects of antioxidants used as food additives. In: Food antioxidants. Springer. 1990: 253-307.

25. Ahmad S, Ullah F, Ayaz M, Sadiq A, Imran M. Antioxidant and anticholinesterase investigations of Rumex hastatus D. Don: potential effectiveness in oxidative stress and neurological disorders. Biol res. 2015; 48:1-8.

26. Mukherjee PK, Kumar V, Mal M, Houghton PJ. Acetylcholinesterase inhibitor from plants. Phytomedicine. 2007;14:289-300.

27. Sharma R. Medicinal plants of India-an encyclopedia. Delhi: Daya Publishing House; 2003. p. 46-7.

28. Ayaz M, Junaid M, Subhan F, Ullah F, Sadiq A, Ahmad S, et al. Heavy metals analysis, phytochemical, phytotoxic 3 and anthelmintic investigations of crude methanolic extract, subsequent fractions and 5 crude saponins from Polygonum hydropiper L. BMC Complement Altern Med. 2014;14:465.

29. Ayaz M, Junaid M, Ahmed J, Ullah F, Sadiq A, Ahmad S, et al. Phenolic contents, antioxidant and anticholinesterase potentials of crude extract, subsequent fractions and crude saponins from Polygonum hydropiper L. BMC Complement Altern Med. 2014;14:145.

30. Chevallier A. The encyclopedia of medicinal plants. London: Dorling Kindersley; 1996. p. 185. ISBN 9-780751-303148.

31. Chen L-W, Wang Y-Q, Wei L-C, Shi M, Chan Y-S. Chinese herbs and herbal extracts for neuroprotection of dopaminergic neurons and potential therapeutic treatment of parkinsons disease. CNS Neurol Disord Drug Targets. 2007;6(4):273-81.

32. Chan Y-C, Wang M-F, Chen Y-C, Yang D-Y, Lee M-S, Cheng F-C. Longterm administration of polygonum multiflorum thunb: Reduces cerebral ischemia-induced infarct volume in gerbils. Am J Chin Med. 2003;31(01):71-7.

33. Li X, Matsumoto K, Murakami Y, Tezuka Y, Wu Y, Kadota S. Neuroprotective effects of Polygonum multiflorum on nigrostriatal dopaminergic degeneration induced by paraquat and maneb in mice. Pharmacol Biochem Behav. 2005;82(2):345-52.

34. Senatore F, Urrunaga Soria E, Urrunaga Soria R, Della Porta G, De Feo V. Essential oils from two Peruvian Satureja species. Flavour Fragance J. 1998:13:1-4.

35. Sadiq A, Mahmood F, Ullah F, Ayaz M, Ahmad S, Haq FU, Khan G, Jan MS. Synthesis, anticholinesterase and antioxidant potentials of ketoesters derivatives of succinimides: a possible role in the management of Alzheimer's. Chem Cent J. 2015; 9(1):31.

36. Zeb A, Sadiq A, Ullah F, Ahmad S, Ayaz M. Investigations of anticholinesterase and antioxidant potentials of methanolic extract, subsequent fractions, crude saponins and flavonoids isolated from Isodon rugosus. Biol Res. 2014;47:76.
37. Kamal Z, Ullah F, Ayaz M, Sadiq A, Ahmad S, Zeb A, Hussain A, Imran M. Anticholinesterse and antioxidant investigations of crude extracts, subsequent fractions, saponins and flavonoids of atriplex laciniata L.: potential effectiveness in Alzheimers and other neurological disorders. Biol res. 2015; 48:1-11.

38. Gracon SI, Knapp MJ, Berghoff WG, Pierce M, DeJong R, Lobbestael SJ, et al. Safety of tacrine: clinical trials, treatment IND, and postmarketing experience. Alzheimer Dis Assoc Disord. 1998;12(2):93-101.

39. Watkins PB, Zimmerman HJ, Knapp MJ, Gracon SI, Lewis KW. Hepatotoxic effects of tacrine administration in patients with Alzheimer's disease. JAMA 1994;271(13):992-8.

40. Cummings JL. Use of cholinesterase inhibitors in clinical practice: evidencebased recommendations. Am J Geriatr Psychiatry. 2003;11(2):131-45.

41. Tariot PN, Cummings $J \mathrm{~L}$, Katz IR, Mintzer J, Perdomo CA, Schwam EM, et al. A randomized, double-blind, placebo-controlled study of the efficacy and safety of donepezil in patients with Alzheimer's disease in the nursing home setting. J Am Geriatr Soc. 2001:49(12):1590-9.

42. Kim K-W, Ha K-T, Park C-S, Jin U-H, Chang HW, Lee I-S, et al. Polygonum cuspidatum, compared with baicalin and berberine, inhibits inducible nitric oxide synthase and cyclooxygenase-2 gene expressions in RAW 264.7 macrophages. Vascul Pharmacol. 2007:47(2):99-107.

43. Hu J-P, Nishishita K, Sakai E, Yoshida H, Kato Y, Tsukuba T, et al. Berberine inhibits RANKL-induced osteoclast formation and survival through suppressing the NF-19 B and Akt pathways. Eur J Pharmacol. 2008;580(1):70-9.

44. Durairajan SSK, Liu L-F, Lu J-H, Chen L-L, Yuan Q, Chung SK, et al. Berberine ameliorates amyloid pathology, gliosis, and cognitive impairment in an Alzheimer's disease transgenic mouse model. Neurobiol Aging. 2012;33(12):2903-19.

45. Asai M, Iwata N, Yoshikawa A, Aizaki Y, Ishiura S, Saido TC, et al. Berberine alters the processing of Alzheimer amyloid precursor protein to decrease Al $\hat{l}^{2}$ secretion. Biochem Biophys Res Commun. 2007;352(2):498-502.

46. Nitsch RM. From acetylcholine to amyloid: neurotransmitters and the pathology of Alzheimer's disease. Neurodegeneration. 1996;5(4):477-82.

47. Vassar R. BACE1 inhibitor drugs in clinical trials for Alzheimers disease. Alzheimers Res Ther. 2014;6(9):89.

48. Ullah F, Ayaz M, Sadiq A, Hussain A, Ahmad S, Imran M, Zeb A. Phenolic, flavonoid contents, anticholinesterase and antioxidant evaluation of Iris germanica var; florentina. Nat Prod Res. (ahead-of-print):1-5.

49. Brahmachari $G$. Role of natural products as a source of Alzheimer's drug leads: An update, in: Natural bioactive molecules: Impacts \& prospects. Oxford: Alpha Science International; 2013. Narosa Publishing House Pvt Ltd, New Delhi, ISBN: 978-1-84265-780-5/978-81-8487-235-4

50. Bassole I, Lamien-Meda A, Bayala B, Obame L, Ilboudo A. Chemical composition and antimicrobial activity of Cymbopogon citratus and Cymbopogon giganteus essential oils alone and in combination. Int J Phycol Phycochem. 2011;18:1070-4.

51. Stein S, Mirokhin D, Tchekhovskoi D, G M. The NIST Mass Spectral Search Program for the NIST/EPA/NIH Mass Spectra Library; Standard Reference Data Program of the National Institute of Standards and Technology: Gaithersburg, MD, USA. 2002.

52. Adams R. Identification of essential oil components by gas chromatography/mass spectrometry. Carol Stream: Allured Publishing; 2007. p. 804.

53. Trevisan MTS, Macedo FW, Meent M, Rhee IK, Verpoorte R. Screening for acetylcholinesterase inhibitors from plants to treat Alzheimer's disease. QuÃmica Nova. 2003;26(3):301-4.

54. Classics Ellman GL, Courtney KD, Andres V, Featherstone RM. A new and rapid colorimetric determination of acetylcholinesterase activity. Biochem Pharmacol. 1961;7:88-95.

55. Braca A, Tommasi ND, Bari LD, Pizza C, Politi M, Morelli I. Antioxidant principles from Bauhinia terapotensis. J Nat Prod. 2001;64(7):892-5.

56. Re R, Pellegrini N, Proteggente A, Pannala A, Yong M, Rice-Evas C. Antioxidant activity applying an improved FBTS radical cation decolorization assay. Free Radic Biol Med. 1999;26(9/10):1231-7.

57. Ruch R. Prevention of cytotoxicity and inhibition of intercellular communication by antioxidant catechins isolated from Chinese green tea. Carcinogenesis. 1989;10:1003-8. 